analysis of a post-marketing surveillance study of 2679 patients in Japan. Mod Rheumatol. 2016 Dec 21:1-11.

[3] Okamura K, Yonemoto Y, Suto T, Okura C, Takagishi K. Efficacy at 52 weeks of daily clinical use of iguratimod in patients with rheumatoid arthritis. Mod Rheumatol. 2015 Jul;25(4):534-9.

Disclosure of Interest: None declared

DOI: 10.1136/annrheumdis-2017-eular.6040

\section{AB0440 IMPACT OF VITAMIN D DEFICIENCY UPON DISEASE ACTIVITY AND IMMUNE DISORDER IN RHEUMATOID ARTHRITIS PATIENTS}

Y. Liu, H.Y. Wen. Rheumatology, the Second Hospital of Shanxi Medical University, Taiyuan, China

Background: Emerging evidence suggests that vitamin D plays an important role in immune regulation.

Objectives: The objective of this work was to determine if patients with rheumatoid arthritis (RA) are at risk for vitamin D deficiency and whether vitamin D levels correlate with disease activity or immune disorders.

Methods: This study was a retrospective research. RA patients who had vitamin $D$ levels and immune function indexes of each other were included. Patients receiving or have received vitamin $\mathrm{D}$, corticosteroids, disease-modifying antirheumatic drugs or a tumor necrosis factor antagonist and those who had hepatic or renal insufficiency were excluded. Multivariate analysis was performed to examine correlations and control for confounding factors.

Results: As suggested threshold $(\leq 25 \mathrm{ng} / \mathrm{ml})$, the overall prevalence of vitamin D insufficiency was 265 of 280 (94.8\%). Mean serum vitamin D insufficiency levels of $11.15 \pm 4.74 \mathrm{ng} / \mathrm{ml}$ for RA patients were significantly lower compared to controls $(31.62 \pm 6.46)(p=0.001)$. Among all the subjects, $208(72.7 \%)$ were females. Vitamin D levels in high disease activity group were lower compared to vitamin $\mathrm{D}$ level in patients with low and moderate disease activity (DAS-28 score $>5.1,3.2-5.1,<3.2$, respectively, $p<0.001$ ) and vitamin $D$ levels had an inverse correlation with DAS28 score ( $\beta$-coefficient- $0.164, p=0.018$, per $1 \mathrm{ng} / \mathrm{ml}$ ). In patients with $\mathrm{RA}$, the levels of vitamin $\mathrm{D}$ were moderately and inversely associated with Th 17 ( $\beta$-coefficient- $0.158, p=0.019$, per $1 \mathrm{ng} / \mathrm{ml})$. However, no significant relationship was found between vitamin $D$ and these variables ( $T$ cell, B cell, NK cell, Treg, Th1, Th2, Th17/Treg) in patients.

Conclusions: Lower levels of vitamin D are associated with worse DAS28

Table 1. Disease activity, immune function indexes with RA as mean \pm standard deviation or number (\%) for total group and based on vitamin D status

\begin{tabular}{lcccc}
\hline Variables & $\begin{array}{c}\text { All } \\
\text { patients } \\
\mathrm{N}=280\end{array}$ & $\begin{array}{c}\text { Patients with } \\
\text { Vitamin } \mathrm{D} \\
\text { insufficiency } \\
\mathrm{N}=265\end{array}$ & $\begin{array}{c}\text { Patients without } \\
\text { Vitamin } \mathrm{D} \\
\text { insufficiency } \\
\mathrm{N}=15\end{array}$ & $\begin{array}{c}\mathrm{P} \text { (Insufficiency } \\
\text { vs no } \\
\text { insufficiency) }\end{array}$ \\
\hline Women & $208(72.7)$ & $201(74.2)$ & $7(33.3)$ & 0.012 \\
Age $(\mathrm{yr})$ & $56.421 \pm 12.325$ & $56.109 \pm 12.225$ & $61.933 \pm 13.215$ & 0.075 \\
Disease & & & & \\
$\quad$ duration $(\mathrm{yr})$ & $9.004 \pm 9.336$ & $9.017 \pm 9.374$ & $8.782 \pm 8.938$ & 0.925 \\
ESR & $59.064 \pm 36.483$ & $59.325 \pm 36.731$ & $54.467 \pm 32.544$ & 0.617 \\
DAS 28 & $4.754 \pm 1.429$ & $4.768 \pm 1.426$ & $4.508 \pm 1.526$ & 0.494 \\
T cell & $1242.473 \pm 585.533$ & $1249.317 \pm 586.751$ & $1122.933 \pm 569.670$ & 0.417 \\
B cell & $204.397 \pm 182.279$ & $208.206 \pm 185.967$ & $137.867 \pm 72.572$ & 0.146 \\
NK cell & $237.419 \pm 187.449$ & $233.782 \pm 188.784$ & $300.933 \pm 153.989$ & 0.178 \\
Th1 & $88.290 \pm 116.113$ & $87.583 \pm 116.660$ & $103.377 \pm 108.907$ & 0.691 \\
Th2 & $12.729 \pm 10.819$ & $12.852 \pm 10.992$ & $10.121 \pm 5.788$ & 0.461 \\
Th17 & $9.271 \pm 9.023$ & $9.330 \pm 9.145$ & $8.010 \pm 6.059$ & 0.669 \\
Treg & $33.710 \pm 28.519$ & $34.060 \pm 29.025$ & $26.257 \pm 12.426$ & 0.424 \\
Th17/Treg & $0.421 \pm 0.639$ & $0.421 \pm 0.647$ & $0.411 \pm 0.445$ & 0.964 \\
\hline
\end{tabular}

Table 2. Multivariate associations of serum $1,25(\mathrm{OH})_{2} D_{3}$ concentrations with $R A(n=280)$

\begin{tabular}{lccc}
\hline Variables & $\beta$-coefficient & $95 \% \mathrm{Cl}$ & $\mathrm{p}$ \\
\hline Gender & -0.241 & -5.337 to -1.562 & 0.001 \\
Age & 0.182 & 0.024 to 0.168 & 0.009 \\
DAS 28 & -0.164 & -1.243 to -1.116 & 0.018 \\
Th 17 & -0.158 & -0.199 to -0.018 & 0.019 \\
\hline
\end{tabular}

igure 3: The correlations between of serum $1,25(\mathrm{OH})_{2} \mathrm{D}_{3}$ levels and $\mathrm{Th}, 17$ levels.

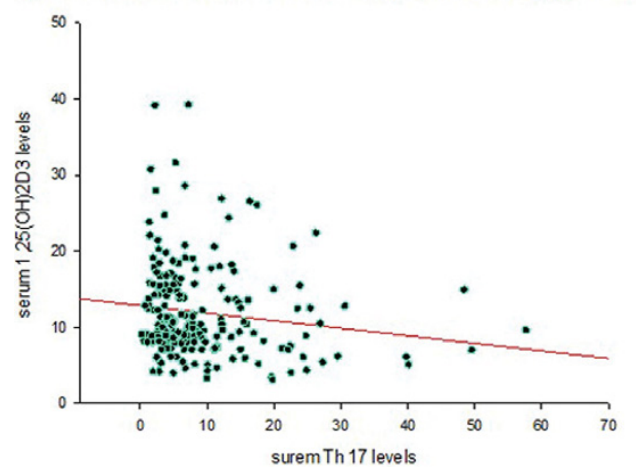

and higher levels of Th17 with RA, especially in female patients. The levels of 1,25-dihydroxycholecalciferol $\left(1,25(\mathrm{OH})_{2} \mathrm{D}_{3}\right)$ could be a marker to monitor the disease activity in RA patients and vitamin $\mathrm{D}$ may be an alternative supplementary treatment for RA.

Acknowledgements: This work was supported by research grants from the National Natural Science Foundation of China (no. 81301532/H0603) and the Shanxi Science and Technology research projects of China (no. 201603D321074). Disclosure of Interest: None declared

DOI: 10.1136/annrheumdis-2017-eular.3202

\section{AB0441 USING OF SUBCUTANEOUS METHOTREXATE IN AGED PATIENTS WITH SEROPOSITIVE RA}

Y. Muraviev, G. Gridneva, E. Luchikhina, N. Demidova, V. Lebedeva, D. Karateev. V. A. Nasonova Research Institute of Rheumatology, Moscow, Russia, Moscow, Russian Federation

Background: Increasing life expectancy is a global process involving multiple nations, thus deeper insights into methotrexate (MTX) therapeutic potential in aged people is of paramount importance, as MTX still remains an anchor DMARD in RA management.

Objectives: To assess the results of 12-months therapy with subcutaneous MTX (SC MTX) injections in RA patients aged more than 60 years.

Methods: The 12 months open study included pts with active RA (DAS28 >3,2), meeting ACR/EULAR (or ACR 1987) criteria, with RA lasting up to 3 years, and naïve to SC MTX. All pts were RF and/or ACPA-positive, $68 \%$ had increased BMI, $31 \%$ - obesity, $8 \%$ were smokers, $25 \%$ were taking oral GCS ( $\leq 10 \mathrm{mg} / \mathrm{day}$ equivalent to prednisolone).All pts were administered SC MTX monotherapy once a week as a DMARD, starting at $10-15 \mathrm{mg} /$ week, with subsequent $5 \mathrm{mg}$ up-titration each 1-2 weeks (to max $30 \mathrm{mg} /$ week) up to achieving the target (remission or minimum disease activity) or up to emergence of an adverse drug reaction (ADR). Folic acid ( $\mathrm{min} 5 \mathrm{mg} /$ week) was administered at any day(s) except for the day of SC MTX injection for ADR prophylaxis. Disease activity was scored using DAS28. GEBA were administered in pts with insufficient SC MTX clinical effect. Pts were monitored within universal institutional REMARKA program, envisaging physical examination, blood analysis and biochemistry panel (including liver enzymes and creatinine). STATISTICA 10 software was used for data processing.

Results: 32 RA pts (28 females, 4 males) were included (mean disease duration $12 \pm 10$ months, mean age $-65,7 \pm 4,7$ years, mean DAS28 score $-5,6 \pm 0,9$. Cumulative SCMT dose by the end of the study reached $264 \pm 180 \mathrm{mg}$ ). The therapeutic target (remission or minimum disease activity based on DAS28 score) was achieved in 20 pts receiving SCMT monotherpay, 12 pts required administration of GEBAs. Adverse drug reactions (ADRs) were documented in 10 pts, including cases of more than one ADR at a time: breast abscess (1), alopecia (2), diarrhea (2), skin rash (1), a metallic aftertaste (1), local post-injection reactions (1), nausea (2), elevation of liver enzymes (3), leucopenia (1), pneumonia (1). There were 5 cases of SC MTX monotherpay discontinuation ( 2 - temporary, and 3 - permanent). The majority of pts (88\%) could manage self-injection without additional training or assistance from medical staff.

Conclusions: $62,5 \%$ of aged RA pts participating in the study managed to achieve the therapeutic target after 12 months of SC MT monotherapy, although $31 \%$ ADRs rate required temporary (2)/permanent (3) SCMT discontinuation.

Disclosure of Interest: None declared

DOI: 10.1136/annrheumdis-2017-eular.2418

\section{SLE, Sjögren's and APS - treatment}

\section{AB0442 REAL-LIFE EXPERIENCE WITH BELIMUMAB IN SYSTEMIC LUPUS ERYTHEMATOSUS (SLE): CONTROL OF DISEASE ACTIVITY AND FLARES IN A MULTICENTER COHORT}

A. Fanouriakis ${ }^{1}$, C. Adamichou ${ }^{2}$, S. Koutsoviti ${ }^{3}$, A. Klagou ${ }^{4}$, C. Tsalapaki ${ }^{5}$, S. Konsta ${ }^{6}$, D. Dimopoulou ${ }^{7}$, S. Ntali ${ }^{8}$, D. Vassilopoulos ${ }^{5}$, P. Konstantopoulou ${ }^{9}$, A. Elezoglou ${ }^{3}$, P. Sidiropoulos ${ }^{2}$, A. Erden ${ }^{10}$, G. Bertsias ${ }^{2}$, D. Boumpas ${ }^{1}$. ${ }^{1}$ Rheumatology and Clinical Immunology, "Attikon" University Hospital, Athens; ${ }^{2}$ Rheumatology, Clinical Immunology and Allergy, University Hospital of Heraklion, Heraklion; ${ }^{3}$ Dept of Rheumatology, "Asklipieion" General Hospital; ${ }^{4}$ Dept of Rheumatology, "G. Gennimatas" General Hospital; 5 2nd Dept of Internal Medicine, "Ippokrateion" General Hospital; ' Dept of Rheumatology,

"Evangelismos" General Hospital, Athens; " Dept of Rheumatology, "Ippokrateion" General Hospital: ${ }^{8}$ Private rheumatologist, Thessaloniki; ${ }^{9}$ Dept. of

Rheumatology, "G. Gennimatas" General Hospital, Athens, Greece; ${ }^{10}$ Dept. of Rheumatology, Hacettepe University, Faculty of Medicine, Ankara, Turkey

Background: Data on the efficacy of belimumab in SLE mainly originate from large randomized clinical trials, whereas reports from real-life clinical practice are lacking

Objectives: To describe the clinical experience from the use of belimumab in Greece since the approval of the drug.

Methods: Multicentre observational study of patients receiving belimumab, with documentation of disease activity (SLEDAI-2K index), achievement of low disease 